\title{
Prevalence and Physical Environmental Conditions as Risk Factor for Pulmonary Tuberculosis in Indonesia 2015
}

\author{
Dian Perwitasari ${ }^{1}$, Oster Suriani Simarmata ${ }^{1}$, Lamria Pangaribuan ${ }^{1}$, Teti Tejayanti ${ }^{1}$, Dina Bisara Lolong ${ }^{1}$, \\ Kristina $^{1}$ \& Qian Long ${ }^{2}$ \\ ${ }^{1}$ Centre for Research and Development of Public Health Efforts, Indonesia \\ ${ }^{2}$ Global Health Research Center, Duke Kunshan University, Kunshan, China \\ Correspondence: Dian Perwitasari, Centre for Research and Development of Public Health Efforts, National \\ Institute Health Research and Development, Ministry of Health, Percetakan Negara Street No.29, Jakarta, \\ Indonesia. Tel: 62-813-8981-5537.
}

Received: Febary 17, 2021 Accepted: April 13, 2021 Online Published: May 8, 2021

doi:10.5539/gjhs.v13n6p36 URL: https://doi.org/10.5539/gjhs.v13n6p36

\begin{abstract}
Objective: The number of tuberculosis (TB) cases in Indonesia is currently very high, so the analysis is needed to describe the environmental conditions at risk of TB disease. The aim of the study was to look at the prevalence of pulmonary TB in 2013-2014 in Indonesia based on the area of residence of the respondents and to see the relationship between the environmental conditions of the prevalence of TB in Indonesia.
\end{abstract}

Material and Methods: The Prevalence SPTB 2013-2014 was used cross-sectional design with national coverage. Sampling selection used multi-staged cluster sampling in the population aged 15 years and above. The analysis data used SPSS program; first analysis was used bivariate and continuing to multivariate analysis.

Result: Tb prevalence rate with bacteriological confirmed was 759 [95\% CI: 590, 961] per 100,000 population in aged 15 years and above. The bivariable analysis shown those participant who live at house with floor $<8 \mathrm{~m} 2 /$ person [95\% CI:1,053,1,710] and those participant who lived in house with kitchen was not separated from the main living area in the house [95\% CI: 1,034,1,669], that was significant related with TB. In the multivariable model, the density characterized by family members with a floor surface $<8 \mathrm{~m} 2 /$ person [ $95 \%$ CI: $1,017,1,671]$ is at risk of developing TB.

Conclusion: This study shows that the effect of the physical environment of living in a crowded household can be a risk factor for TB transmission. The other factor might be influence of infection $\mathrm{Tb}$ in the community.

Keywords: Prevalence, Pulmonary tuberculosis (TB), Environmental, Risk factor

\section{Introduction}

Tuberculosis (TB) is a major communicable disease health problem and leading cause of morbidity and mortality worldwide. Accounting for about 9.6 million new cases and 1.5 million deaths annually (Indonesia National TB Program (NTP), 2018; Ministry of Health, 2018). More than two thirds of the global TB burden is reported in Africa and Asia, and in absolute terms India, Indonesia and China account for the highest number of TB cases amounting to $43 \%$ of the global burden. (Raviglione\& Sulis, 2016) One of MDGs action in point seven that focus on ensure environmental sustainability before accelerating to Sustainable Development Goals (SDGs) (World Health Organisation, 2015; UNDP \& World Bank Group, 2016). Base on SDGs 2016 agenda about TB Strategy to prevent, control and end the TB epidemic that is cover three dimensions: economic, social and environmental. The health scope in SDGs has been considerably broadened compared to the MDGs (Lönnroth \& Raviglione, 2015).

Indonesia carries the fifth highest tuberculosis (TB) burden in the world. According to Indonesia National TB program, the TB incidence all case was 391 per 100.000 populations. TB Incidence In 2017 was 898.000 in range $821.000-984.000$. While in 2017 the number of TB cases is currently 254 per 100,000 or 25.40 per 1 million population.(Data and Information Centre, Ministry of Health, Indonesia, 2018) the number of new TB cases in Indonesia was 420,994 cases in 2017(Data and Information Centre, Ministry of Health, Indonesia, 2018; Ministry of Health, 2018). In 2015, Regulation of the Minister of Health No. 67 of 2016 concerning Tuberculosis Prevention sets the national TB Control Program target of elimination in 2035 and Indonesia Free of TB in 2050 (Ministry of Health, 2019). 
Indonesia data Ministry of Health 2018 reported an epidemiological perspective that looks at disease events as a result of interactions between three host components (hosts), causes (agents), and environment (environment) can be examined the risk factors(Data and Information Centre, Ministry of Health, Indonesia, 2018). Srivastava, 2015 study was discussed an increase in the number of cases of positive smear pulmonary TB is due to the risk factors that trigger it such as environmental, demographic, socio-economic, and behavioural risk factors(Sirvastava, Kant and Verma, 2015). The study from Central Java shown that people is living at a home with an unhealthy condition will accelerate the transmission of TB disease (Wulandari, Nurjazuli, \& Adi, 2015). Another study from Pakistan proved of ventilation that does meet the requirements residents of the house, and house contact with pulmonary TB sufferers are risk factors for infection with M. tuberculosis germs (Khaliq et al., 2015). Study in North Minahasa District shown Indoor air pollution can increase the risk of Germs infection (L. et al., 2015). Tuberculosis can be develop with the source of indoor air pollution is usually from kitchen smoke, and cigarette smoke (Sayuti, 2013). Case Control study in Northern Quebec determined Reducing household crowding may contribute to TB prevention (Khan et al., 2016). There are several factors that contribute to the prevalence of pulmonary tuberculosis including population risk factors such as age group(Negin, Abimbola, \& Marais, 2015), gender and regional classification, while the factors that most influence the onset of this disease are environmental risk factors such as; floor area, type of floor, ventilation, window, light, kitchen location, fuel used in the house and the presence of family members who smoke in the house(TB DOTS Strategy Coordination, 2014).

Various efforts have been made by the government and the community to eliminate the incidence of TB has not shown satisfactory results. Many obstacles were encountered in an effort to suppress the spread of this case. The increase in TB cases throughout Indonesia is still so high that an analysis is needed that aims to look TB prevalence by location and demographic characteristics and association between living condition and TB. The results of this analysis are expected to be used as useful information for all parties, as an effort to prevent, mitigate and control the spread of TB.

\section{Method}

\subsection{Study Design and Setting}

The Prevalence SPTB 2013-2014 was used cross-sectional design with national coverage. Sampling selection used multi-staged cluster sampling in the population aged 15 years and above. Data cleaning and analysis finished in April 2015. The survey was conducted by the National Institute of Health (Ministry of Health, 2015).

This research is a survey conducted specifically to obtain national tuberculosis (TB) prevalence data in the community that was carried out in 156 clusters, 136 districts / cities in 34 provinces. The number of clusters was distributed in proportion to the size of the population (2010 census): 46 for Sumatera, 64 for Java Bali, and 46 for other regions. Data collection started in April 2013 and finished in June 2014 (Ministry of Health, 2015).

The nationally representative, community-based survey, covering the characteristics of respondents (Age 15 years and above, sex, education level and region), the characteristics of the area (urban and rural), the condition of residential buildings such as floor type, sufficient ventilation, sufficient natural light and location of kitchen. Another behaviour variable such as floor surface (density of member house hold), open windows regularly, fuel used in the house, any family member smoked in the house.

\subsection{Participant Characteristic}

Age was calculated based on the length of the participant life in accordance with the last birthday, grouped into 3 groups i.e. 15-34 years, 35-54 years, and more than 55 years. Regional classifications are grouped into urban and rural areas. The region is divided into three clusters i.e. Sumatra, Java-Bali and Eastern Indonesia (KTI). Classification of regions and regions is based on groupings from the Central Statistics Agency.

\subsection{Data Collections}

Data was collected using questioner design by SPTB 2013 - 2014 base on WHO recommendation and survey observation. Some variable for measurement such as: Education is the level of formal education completed (the last diploma owned by participants) grouped into graduate junior high school and above ( $\geq$ Junior high school $/ \geq$ SMP) and non-graduate Junior high school and below ( $<$ junior high school $/<$ SMP). Environmental factor variables include floor surface, floor type, open window regularly, sufficient ventilation, sufficient natural light, location of kitchen, fuel used in the house and any family members smoke in the house. Any member was smoking behaviour inside the house was collected from bacteria confirmed. The variable density of member house hold is calculated based on the number of households that occupy one house divided by the size of floor surface(Ministry of Health, 2011; Darmiah, Santoso and Maharso, 2015; Kurniawati and Sulistiyorini, 2019). We were chosen aged 15 years and above as it corresponds to the age group within the age range defined as adolescent in Indonesia. It 
clarified that the age range of adolescent is mature in thought and capable of decision taking (Dogin, 1895; Curtis, 2015; Vaughan, Waisman, William, \& Rodgers, 2015).

\subsection{Data Analysis}

The study was secondary analysis of the Survey Prevalence Tuberculosis in 2013 - 2014 (SPTB 2013-2014). The analysis data was used a subset data of SPTB 2013-1014. The main objective was bacteriologically confirmed TB prevalence rates for people aged 15 years and over, in addition to some data on risk factors, knowledge, attitudes and behaviour of the community about TB disease (Ministry of Health, 2015).

TB prevalence estimate (p), design effect (def), estimated proportion of population aged 15 years and above (a), relative precision (d), and minimum participation rate (r). Estimated TB prevalence based on the results of NPS 2004 was 104 per 100000 population (Soemantri, Lolong, \& Senewe, 2005). Considering the geographic similarity and low HIV prevalence of Indonesia, doubling the notification might serve as an alternative, conservative way to estimate smear-positive TB prevalence. Smear-positive notification was 78 per 100000 population in 2010. Therefore, we assumed a prevalence of 156 per 100000 . The parameters used to calculate the sample size were: Estimated prevalence (p): 156/100 000; Proportion of population aged 15 years and above (a): $71.1 \%$; Confidence interval of $95 \%$ or $\alpha=5 \%$; Relative precision (d): $20 \%$, according to WHO recommendation; Minimum participation rate (r): $85 \%$ according to WHO recommendation; Cluster size (M): 500 considering weekly operation cycle and following WHO recommendation (400-800); Design effect (def): 1.5 ( $\mathrm{k}>0.6$ cluster variation was estimated to be high based on 2004 experience). Calculation of sample size applied the formulas below:

$$
n_{0}=\frac{1.96^{2}(1-p)}{d^{2} p} \times \text { deff } \rightarrow n_{0}=\frac{1,96^{2}(1-0.00156)}{0.2^{2} \times 0.00156} \times 1,5=92,202.09
$$

Because the survey considered those aged 15 years and above to be the eligible population, sample size was calculated as follows:

$$
n_{a}=n_{0} \times a \rightarrow n_{a}=92,202.09 \times 0.711=65,555.69
$$

Minimum participation rate was $85 \%$, so the sample size was adjusted as follows:

$$
n=\frac{n_{\alpha}}{r} \rightarrow n=\frac{65,555.69}{0.85}=77,124.34 \approx 78,000
$$

This article is a descriptive analysis using SPSS program with cross-sectional design. First data analysis was used bivariate variable and continuing to multivariate analysis after result significant was shown. Variables were taken the characteristics of respondents who were positively diagnosed on microscopic examination of smears, and did not take respondents who only had pulmonary TB symptoms, with consideration to get a clearer picture of the relationship between the cases of pulmonary tuberculosis by confirmed smear positive Mycobacteria Tuberculosis (MTB) as a dependent variables. The independent variables studied include characteristics of the living environment and behaviour that influence the incidence of pulmonary TB.

\subsection{Ethical Approval}

The study protocol was approved by The Committee on Health Research Ethic of The National Institute Health Research and Development, Ministry Of Health, Indonesia (KE. 01.01/EC/651/ 2012). Informed consent was confirmed (or waived) by the Ethic Committee.

\section{Results}

The socio-demographic characteristics of the participants were given in Table 1. A total participant who was analyse were 63.202 participants (26.703 household) in rural and urban areas in all provinces were included in the analysis. The number of participant who have positive bacteriological confirm of TB case 426 participants but after cleaning as the variables needed only 390 . 
The prevalence survey tuberculosis results estimates both smear-positive and bacteriologically confirmed were higher among men (1082.7 per 100.000 population) than among women (460.6 per 100.000 population). The prevalence increased in age with the highest estimated prevalence of pulmonary TB are in 65+ age group (1581.7 per 100.000 population).

Table 1. Estimated bacteriologically confirmed pulmonary TB prevalence among population aged 15 years and above by age groups, sex, urban/rural classification, and region (per 100.000 population)

\begin{tabular}{lcrcc}
\hline Characteristics & Prevalence estimates & SE & CI 95\% & RSE (\%) \\
\hline Age group & & & & 17.0 \\
$15-24$ & 360.8 & 61.5 & $254.3-494.7$ & 14.6 \\
$25-34$ & 753.4 & 110.3 & $561.8-995.0$ & 14.8 \\
$35-44$ & 713.8 & 105.5 & $527.4-941.0$ & 15.3 \\
$45-54$ & 835.5 & 127.9 & $608.9-1108.3$ & 16.5 \\
$55-64$ & 1029.5 & 169.7 & $734.1-1398.5$ & 16.6 \\
$65+$ & 1581.7 & 263.3 & $1122.7-2153.7$ & 10.9 \\
\hline Sex & & & & 13.2 \\
Male & 1082.7 & 118.5 & $872.8-1337.3$ & 13.7 \\
Female & 460.6 & 60.6 & $353.6-590.8$ & 11.2 \\
\hline Urban/rural classification & & & 14.0 \\
Rural & 674.2 & 92.2 & $511.9-873.6$ & 13.4 \\
Urban & 845.8 & 94.4 & $678.2-1047.7$ & 13.8 \\
\hline Region & & & 12.5 \\
Java-Bali & 593.1 & 82.8 & $447.2-770.6$ & \\
Sumatera & 122.7 & $696.7-1176.7$ & \\
Others & 913.1 & 116.4 & $634.7-1091.8$ & $589.7-960.8$ \\
\hline TOTAL & 842.1 & 95.1 & & \\
\hline Sorce: Sur & 759.1 & & & \\
\hline
\end{tabular}

Source: Survey Prevalence Tuberculosis 2015.

TB prevalence with bacteriological confirmed is 759 (95\% CI 590-961) per 100,000 population in aged 15 years and above with a design effect of 1.77. Prevalence increases in age, population in urban areas is higher than in rural areas, and Sumatra's density is higher than in other regions. (Table 1)

The analysis bivariate between dependent variable (Urban-Rural) and independent variable (Socio-demographic characteristics and living condition) shown in Table 2. The percentage of $38 \%$ participants in the age range of $35-$ 54 years and more of all lived in urban areas. Almost of participants confirmed were males than female. The percentage of TB participants is higher in non-graduate Junior high school and below $(<$ junior high school $)$ than Graduate junior high school and above ( $\geq$ Junior high school) with differences around $10,2 \%$. Participants who living in $8 \mathrm{~m}^{2} /$ person floor surface more than participants who living in a floor surface under than $8 \mathrm{~m}^{2} /$ person with large difference of 57\%. Participants has living at house with not soil floor more than participants who living at house with soil floor has large differences of $89,8 \%$. Participants who open window regularly has more than participants who not opened window regularly with a differences of percentage as $47,6 \%$. The percentage of participants who have enough sufficient ventilation more than participants who have deficient ventilation with a lot of differences of $73,4 \%$. Likewise for house have enough sufficient natural light more than house with less natural light have a differences of $77 \%$. The percentage participants who lived separated from the main living area (living room or bedroom) in the house more than participants who lived non separated from the main living area in the house with a difference of 55,5\%. The percentage of participants who used electric/gas/LPG more than participants who used Wood/Charcoal/Kerosene with a differences of $13,8 \%$. Participants who lived with another family member smoked in the house more than participants who lived without another family member smoked in the house with differences of $44,6 \%$. 
Table 2. Socio-demographic characteristics and living condition of TB participants by rural and urban

\begin{tabular}{|c|c|c|c|c|}
\hline Characteristic & Total \% (n) & Rural \% (n) & Urban \% (n) & Pvalue \\
\hline Age & & & & 0,001 \\
\hline $15-34$ & $32,1(125)$ & $24,0(43)$ & $38,9(82)$ & \\
\hline $35-54$ & $37,9(148)$ & $38,0(68)$ & $37,9(80)$ & \\
\hline $55+$ & $30,0(117)$ & $38,0(68)$ & $23,2(49)$ & \\
\hline Sex & & & & 0,004 \\
\hline Female & $32,8(128)$ & $40,2(72)$ & $26,5(56)$ & \\
\hline Male & $67,2(262)$ & $59,8(107)$ & $73,5(155)$ & \\
\hline Education & & & & 0,000 \\
\hline $\begin{array}{l}\text { Graduate junior high school and above } \\
\text { ( } \geq \text { Junior high school) }\end{array}$ & $44,9(175)$ & $27,9(50)$ & $59,2(125)$ & \\
\hline $\begin{array}{l}\text { Non graduate Junior high school and below (< } \\
\text { junior high school) }\end{array}$ & $55,1(215)$ & $72,1(129)$ & $40,8(86)$ & \\
\hline Floor surface (density) & & & & 0,545 \\
\hline$\geq 8 \mathrm{~m}^{2} /$ person & $78,5(306)$ & $77,1((138)$ & $79,6(168)$ & \\
\hline$<8 \mathrm{~m}^{2} /$ person & $21,5(84)$ & $22,9(41)$ & $20,4(43)$ & \\
\hline Floor type & & & & 0,007 \\
\hline Not soil & $94,9(370)$ & $91,6(164)$ & $97,6(206)$ & \\
\hline Soil & $5,1(20)$ & $8,4(15)$ & $2,4(5)$ & \\
\hline Open the windows regularly & & & & 0,058 \\
\hline Yes & $73,8(288)$ & $69,3(124)$ & $77,7(164)$ & \\
\hline No & $26,2(102)$ & $30,7(55)$ & $22,3(47)$ & \\
\hline Sufficient ventilation & & & & 0,033 \\
\hline Yes & $86,7(338)$ & $82,7(148)$ & $90,0(190)$ & \\
\hline No & $13,3(52)$ & $17,3(31)$ & $10,0(21)$ & \\
\hline Sufficient natural light & & & & 0,287 \\
\hline Yes & $88,5(345)$ & $86,6(155)$ & $90,0(190)$ & \\
\hline No & $11,5(45)$ & $13,4(45)$ & $10,0(21)$ & \\
\hline Location of kitchen & & & & 0,148 \\
\hline $\begin{array}{l}\text { Separated from the main living area (living room or } \\
\text { bedroom) in the house }\end{array}$ & $77,7(303)$ & $81,0(145)$ & $74,9(158)$ & \\
\hline Not separated from the main living area in the house & $22,3(87)$ & $19,0(34)$ & $25,1(53)$ & \\
\hline Fuel Used in the House & & & & 0,000 \\
\hline Electric/Gas/LPG & $56,9(222)$ & $36,3(65)$ & $74,4(157)$ & \\
\hline Wood/Charcoal/Kerosene & $43,1(168)$ & $63,7(114)$ & $25,6(54)$ & \\
\hline Any family member smoked in the house & & & & 0,030 \\
\hline No & $27,7(108)$ & $22,3(40)$ & $32,2(68)$ & \\
\hline Yes & $72,3(282)$ & $77, \&(139)$ & $67,8(143)$ & \\
\hline
\end{tabular}

The analysis bivariate between dependent variable (region) and independent variable (Socio-demographic characteristics and living condition) shown in table 3 . The total number of participants with bacteria confirmed that living in across regions. Most of participants was in the age range of 35-54 years and lived in Java-Bali region. The 
most respondent who bacteria confirmed was males and mostly lived in others region. The participants with education non graduate junior high school and below ( $<$ junior high school) are mostly bacteria confirmed and lived in Java-Bali region (62,7\%). Density of member house hold based on floor surface that was $\geq 8 \mathrm{~m} 2 /$ person in region Java-Bali which has a higher density than another regions $(85,1 \%)$. Base on variables which have the highest results came from others region such as floor type (98,4\%), open windows regularly 989,8\%), Sufficient ventilation $(93,8 \%)$ and Sufficient natural light $(93,8 \%)$. Based on the analysis results that participants who live at houses with kitchen locations that are not separate from the main room are mostly in the Java-Bali region, that is equal to $83.6 \%$. In the other hand, using fuel for household purposes are participants who use gas / LPG is in the other region with a percentage of $73.4 \%$. Another thing that supports the finding of participants with bacterial confirmation is participant who lived with family members of smokers were in other areas by $78.9 \%$.

Table 3. Socio-demographic characteristics and living condition of TB participants across regions

\begin{tabular}{|c|c|c|c|c|}
\hline Characteristic & Java-Bali \% (n) & Sumatera \% (n) & Other \% (n) & P value \\
\hline Age & & & & 0,214 \\
\hline $15-34$ & $28,4(38)$ & $32,8(42)$ & $35,2(45)$ & \\
\hline $35-54$ & $40,3(54)$ & $32,0(41)$ & $41,4(53)$ & \\
\hline $55+$ & $31,3(42)$ & $35,2(45)$ & $23,4(30)$ & \\
\hline Sex & & & & 0,004 \\
\hline Female & $33,4(45)$ & $42,2(54)$ & $22,7(29)$ & \\
\hline Male & $66,4(89)$ & $57,8(74)$ & $77,3(99)$ & \\
\hline Education & & & & 0,003 \\
\hline $\begin{array}{l}\text { Graduate junior high school and above ( } \geq \text { Junior } \\
\text { high school) }\end{array}$ & $37,3(50)$ & $40,6(52)$ & $57,0(73)$ & \\
\hline $\begin{array}{l}\text { Non graduate Junior high school and below }(< \\
\text { junior high school) }\end{array}$ & $62,7(84)$ & $59,3(76)$ & $43,0(55)$ & \\
\hline Floor surface (density) & & & & 0,047 \\
\hline$\geq 8 \mathrm{~m}^{2} /$ person & $85,1(114)$ & $72,7(93)$ & $77,3(99)$ & \\
\hline$<8 \mathrm{~m}^{2} /$ person & $14,9(20)$ & $27,3(35)$ & $22,7(29)$ & \\
\hline Floor type & & & & 0,050 \\
\hline Not soil & $91,8(123)$ & $94,5(121)$ & $98,4(126)$ & \\
\hline Soil & $8,2(11)$ & $5,5(7)$ & $1,6(2)$ & \\
\hline Open the windows regularly & & & & 0,000 \\
\hline Yes & $51,5(69)$ & $81,3(104)$ & $89,8(115)$ & \\
\hline No & $48,5(65)$ & $18,8(24)$ & $10,2(13)$ & \\
\hline Sufficient ventilation & & & & 0,001 \\
\hline Yes & $78,4(105)$ & $88,3(113)$ & $93,8(120)$ & \\
\hline No & $21,6(29)$ & $11,7(15)$ & $6,3(8)$ & \\
\hline Sufficient natural light & & & & 0,005 \\
\hline Yes & $81,3(109)$ & $90,6(116)$ & $93,8(120)$ & \\
\hline No & $18,7(25)$ & $9,4(12)$ & $6,5(8)$ & \\
\hline Location of kitchen & & & & 0,098 \\
\hline $\begin{array}{l}\text { Separated from the main living area (living room } \\
\text { or bedroom) in the house }\end{array}$ & $83,6(112)$ & $72,7(93)$ & $76,6(98)$ & \\
\hline $\begin{array}{l}\text { Not separated from the main living area in the } \\
\text { house }\end{array}$ & $16,4(22)$ & $27,3(35)$ & $23,4(30)$ & \\
\hline
\end{tabular}




\begin{tabular}{llll}
\hline Fuel Used in the House & & & 0,000 \\
Electric/Gas/LPG & $66,4(89)$ & $30,5(39)$ & $73,4(94)$ \\
Wood/Charcoal/Kerosene & $33,6(45)$ & $69,5(89)$ & $26,6(34)$ \\
\hline Any family member smoked in the house & & & 0,077 \\
No & $33,6(45)$ & $28,1(36)$ & $21,1(27)$ \\
Yes & $66,4(89)$ & $71,9(92)$ & $78,9(101)$ \\
\hline
\end{tabular}

The crude odds ratio association between socio-demographic and living condition and TB shown that the participants in aged range $35-55^{+}$in rural areas in others region were more likely to TB bacteria confirm. In all regions, Female were less likely to report TB bacteria confirmed compared to males in urban area. Education was significantly associated with TB bacteria confirmed in all regions. (Table 4) Those participants who attended Non graduate Junior high school and below ( $<$ junior high school) more reported of TB bacteria confirmed in rural area in Java-Bali region (Odd ratio [OR] $=1.464,95 \%$ confidence interval $[\mathrm{CI}]=(1,199-1,789)$. Base on location, those participants who live in urban area more likely reported TB bacteria confirmed $(\mathrm{OR}=1,327,95 \%$ CI 1,0871,620) compared with those who lived in rural area. In the other hand, those participants who live in Sumatera $(\mathrm{OR}=1,472,95 \%$, CI1,154-1,877) and Other $(\mathrm{OR}=1,427,95 \%$, CI 1,119-1,819) region more likely reported TB bacteria confirmed than Java-Bali region.

Bivariate analysis of the physical environment with the dependent variable, obtained significant variable results shown only two variables whose related significantly with TB bacteria confirmed, i.e. those participant who live at house with floor $<8 \mathrm{~m} 2 /$ person $(\mathrm{OR}=1,342,95 \%$ CI $1,053-1,710)$ and those participant who lived in house with kitchen was not separated from the main living area in the house (OR=1,314, 95\% CI 1,034-1,669).

Table 4. Determinants of having TB in Indonesia, 2015

\begin{tabular}{|c|c|c|c|c|}
\hline & $\begin{array}{l}\text { Crude Odds Ratio } \\
(95 \% \mathrm{CI})\end{array}$ & $\begin{array}{l}\text { Adjusting for location } \\
\text { (urban/rural) and } \\
\text { region, Odds ratio } \\
(95 \% \mathrm{CI})\end{array}$ & $\begin{array}{l}\text { Adjusting for age, } \\
\text { gender, education, } \\
\text { location and region, } \\
\text { Odds ratio }(95 \% \mathrm{CI})\end{array}$ & $\begin{array}{l}\text { Adjusting for all } \\
\text { variables, Odds ratio } \\
(95 \% \mathrm{CI})\end{array}$ \\
\hline \multicolumn{5}{|l|}{ Age } \\
\hline \multicolumn{5}{|l|}{$15-34$} \\
\hline $35-54$ & $1,332(1,049-1,691)$ & & & $1,275(0,997-1,630)$ \\
\hline $55+$ & $2,271(1,763-2,925)$ & & & $2,046(1,548-2,703)$ \\
\hline \multicolumn{5}{|l|}{ Sex } \\
\hline \multicolumn{5}{|l|}{ Female } \\
\hline Male & $2,360(1,909-2,917)$ & & & $2,402(1,940-2,974)$ \\
\hline \multicolumn{5}{|l|}{ Education } \\
\hline \multicolumn{5}{|l|}{$\begin{array}{l}\text { Graduate junior high school } \\
\text { and above }(\geq \text { Junior high } \\
\text { school) }\end{array}$} \\
\hline $\begin{array}{l}\text { Non graduate Junior high } \\
\text { school and below ( }<\text { junior } \\
\text { high school) }\end{array}$ & $1,464(1,199-1,789)$ & & & $1,443(1,145-1,818)$ \\
\hline \multicolumn{5}{|l|}{ Location } \\
\hline \multicolumn{5}{|l|}{ Rural } \\
\hline Urban & $1,327(1,087-1,620)$ & & & $1,528(1,218-1,917)$ \\
\hline
\end{tabular}




\begin{tabular}{|c|c|c|c|c|}
\hline \multicolumn{5}{|l|}{ Region } \\
\hline \multicolumn{5}{|l|}{ Java - Bali } \\
\hline Others & $1,427(1,119-1,819)$ & & & $1,444(1,103-1,890)$ \\
\hline Sumatera & $1,472(1,154-1,877)$ & & & $1,524(1,172-1,981)$ \\
\hline \multicolumn{5}{|l|}{ Floor surface } \\
\hline \multicolumn{5}{|l|}{$\geq 8 \mathrm{~m}^{2} /$ person } \\
\hline$<8 \mathrm{~m}^{2} /$ person & $1,342(1,053-1,710)$ & $1,267(0,992-1,617)$ & $1,303(1,017-1,671)$ & $1,298(1,010-1,668)$ \\
\hline \multicolumn{5}{|l|}{ Floor type } \\
\hline \multicolumn{5}{|l|}{ Not soil } \\
\hline Soil & $0,805(0,513-1,264)$ & $0,974(0,616-1,542)$ & $0,918(0,579-1,454)$ & $0,874(0,550-1,390)$ \\
\hline \multicolumn{5}{|l|}{ Open the windows regularly } \\
\hline \multicolumn{5}{|l|}{ Yes } \\
\hline No & $0,849(0,677-1,064)$ & $1,008(0,792-1,282)$ & $0,992(0,778-1,264)$ & $0,933(0,718-1,213)$ \\
\hline \multicolumn{5}{|l|}{ Sufficient ventilation } \\
\hline \multicolumn{5}{|l|}{ Yes } \\
\hline No & $0,981(0,732-1,314)$ & $1,104(0,820-1,487)$ & $1,069(0,793-1,441)$ & $0,982(0,688-1,403)$ \\
\hline \multicolumn{5}{|l|}{ Sufficient natural light } \\
\hline \multicolumn{5}{|l|}{ Yes } \\
\hline No & $1,084(0,794-1,480)$ & $1,181(0,863-1,619)$ & $1,164(0,849-1,595)$ & $1,172(0,802-1,711)$ \\
\hline \multicolumn{5}{|l|}{ Location of kitchen } \\
\hline \multicolumn{5}{|l|}{$\begin{array}{l}\text { Separated from the main living } \\
\text { area (living room or bedroom) } \\
\text { in the house }\end{array}$} \\
\hline $\begin{array}{l}\text { Not separated from the main } \\
\text { living area in the house }\end{array}$ & $1,314(1,034-1,669)$ & $1,189(0,931-1,517)$ & $1,178(0,922-1,504)$ & $1,178(0,922-1,507)$ \\
\hline \multicolumn{5}{|l|}{ Fuel Used in the House } \\
\hline \multicolumn{5}{|l|}{ Electric/Gas/LPG } \\
\hline Wood/Charcoal/Kerosene & $1,068(0,874-1,306)$ & $1,173(0,936-1,469)$ & $1,062(0,845-1,333)$ & $1,048(0,833-1,318)$ \\
\hline \multicolumn{5}{|l|}{$\begin{array}{l}\text { Any family member } \\
\text { smoked in the house }\end{array}$} \\
\hline \multicolumn{5}{|l|}{ No } \\
\hline Yes & $1,101(0,882-1,376)$ & $1,117(0.893-1,397)$ & $1,049(0,837-1,317)$ & $1,035(0,824-1,299)$ \\
\hline
\end{tabular}

The association between socio-demographic characteristics and living conditions and TB bacteria confirmed for location (urban/rural) and region for TB determinants were indicate in Table 4. The adjust association between living condition and TB bacteria confirm to for age, sex, education, location and region in the multivariate analysis. All variable entered simultaneously for multivariate analysis using logistic regression. Variables that have a $\mathrm{P}$ value $>0.05$ in multivariate analysis are thought to not affect the occurrence of TB excluded one by one by looking at the largest $P$ value. Variables that have a $P$ value $>0.05$ but are substantially thought to influence the occurrence of TB, then these variables are still included in the analysis. Variables related to the occurrence of TB but have a value of $\mathrm{P}>0.05$ but in substance these variables are strongly suspected to influence the occurrence of TB, so in the final analysis these variables are still included in multivariate analysis.

The multivariate analysis adjusted for location and region were shown none of variable was significant. In the other hand, the analyses for age, gender, education, location and region that the significant variable only floor surface $(\mathrm{OR}=1,303,95 \%, \mathrm{CI}=1,017-1,671)$. The multivariate analysis adjusting for all variables were shown the 
demography variable was significant, but for physical environment only floor surface was significant with $\mathrm{OR}=$ $1,298,95 \%, \mathrm{CI}=1,010-1,668$.

\section{Discussion}

All research variables related to risk factors were taken in this study,(Ministry of Health, 2015) but not all variable in survey research discussed in this article. This study has some limitations which variable was members smoked in house only based on interview from member and other member of house hold; In the variable floor surface is not seen by individually but the measure was used households; and the all participants was analysed who diagnosed with pulmonary TB were only based on microscopic confirmation of the bacteria.

During period when the incidence of TB dramatically increased in this country, the number of people was the only housing characteristic associated with newly diagnosed TB infection. It was associated among participants who had lived with TB participants. The TB prevalence rate was the highest among older age groups (55 years and above). This is slightly different from the Basic Health Research (RISKESDAS, 2013) data which states that the prevalence of pulmonary TB participants is higher in the age group $>35$ years (Data and Information Centre, Ministry of Health, Indonesia, 2016). TB reactivation and longer duration of exposure may be the reasons. However, if we calculated the absolute TB prevalence, the burden is still very high among productive age groups (Data source in Prevalence Survey Tuberculosis 2013-2014, Ministry of Health, 2015)(Ministry of Health, 2015). This indicates that TB transmission is still high (Ministry of Health, 2015; Khan et al., 2016).

Comparisons of sex in TB prevalence and notification highlight sex differences in the number of male are more likely than female to have a timely TB diagnosis. This number is related to the presence of men who come more during the survey than those who want to come to health facilities. In addition, there are more likely men who do not pay attention to health than women, so the possibility of treatment and recovery is more women than men. This is in line with the meta-analysis conducted by Katherine et al. in 2016, which stated that the number of pulmonary TB participants seeking treatment were more women than men (Horton et al., 2016). According to WHO, TB prevalence among males were higher than among females (smear-positive TB prevalence of 393 per 100000 , and bacteriologically confirmed TB prevalence of 1.082 per 100000 among men vs smear-positive TB prevalence of 131 per 100000 and bacteriologically confirmed TB prevalence of 461 per 100000 among women) (WHO, 2014). In TB NPS in other countries, TB prevalence in men were also higher than in women (Ministry of Health of Myanmar, 2010; Kebede et al., 2014; Mao et al., 2014). It is possible that men were more exposed to TB risk factors such as smoking and that they did not seek treatment as early as women. In this survey the proportion of male participants who reported smoking were $68.5 \%$, while it was just $3.7 \%$ among females. Basic health survey results of 2013 found that the proportion of men who smoked were $56.7 \%$ compared to $1.9 \%$ of women (National Institute Health Research and Development, 2013). In addition to age and sex differences in susceptibility related to biologic mechanisms, socioeconomic and cultural factors may also play a role in determining age and sex differences in the rates of infection, progression to disease, and treatment outcome. Many factors may changes the structural and immunological host defence system which increases the risk of the infection (Khaliq et al., 2015).

The distribution of pulmonary TB participants in 2015 were more likely to live in cities. One factor that causes a high number of cases, is the possibility that the population in urban areas is more than those who live in rural areas. Occupancy density is probably one of the risk factors that can cause high rates of pulmonary TB participants in urban areas (Union, Tuberculosis and Disease, 2014). There is no different from research conducted on Solomon Island where residents residing in urban areas have higher TB cases than in rural areas (Union, Tuberculosis and Disease, 2014). This is because many industry sectors and air pollution from vehicles. In addition, there is transmission from outside the region that migrates with the term transfer out to the city (Union, Tuberculosis and Disease, 2014; Aldridge et al., 2016). Another thing mentions the number of TB participants who seek treatment in urban areas because of supporting facilities, so the number of participants recorded in urban areas is more than in rural areas (Tobin-West \& Isodje, 2016; Rahman \& Ahmed, 2017).

According to the results above, other regions of Indonesia covering the eastern region, are the highest endemic areas of pulmonary TB. Possible cases are high in the area due to poor nutritional status, improper living environment, and poorly maintained hygiene (Ministry of Health, 2011). Besides that, health facilities in the eastern part of Indonesia are still inadequate, so that treatment and public access to health facilities are still needed (Ministry of Health, 2011). There is still a lack of public knowledge about the importance of maintaining health in order to avoid TB disease (Ministry of Health, 2011).

Environmental factors (floor surface, type of floor, windows opened regularly, adequate ventilation, sufficient natural lighting, kitchen location, for households with kitchen not separated from the main living area, any family member smoked in the house influences the development of TB disease(Data and Information Centre, Ministry of 
Health, Indonesia, 2018). The results of this study state that the significant cases of TB with bacteria confirm are obtained in environment with a floor area of $<8 \mathrm{~m}^{2}$ / person that relevant with bacteria transmission can spreading in small area inside house.

In the other hand, that non-significant result for type of floor that is not soil, sufficient natural lighting, adequate ventilation, kitchen location separate from the main room. This shows that physically environment cannot be risk as a factor of TB transmission. Different from some research results that show that physically environmental factors can be a risk of developing TB disease (Sirvastava, Kant, \& Verma, 2015; Wulandari, Nurjazuli, \& Adi, 2015; Qadeer et al., 2016). The results of the highest prevalence of environmental risk factors in this survey indicate that the type of floor that is not soil has a high prevalence compared to other environmental factors. This shows that floors other than soil have a high risk of TB transmission. This result is in line with research conducted by Agustina 2015 which states that the type of floor has a significant relationship with transmission of TB in the home (Wulandari, Nurjazuli, \& Adi, 2015). Little is known about the role of home ventilation in the transmission of M. tuberculosis. Although the level of ventilation in health care settings has been shown to affect the risk of TB infection, the results of the bivariate analysis conducted for this sample indicate that there is no association with transmission of TB in the home. This is in line with the research conducted by Khan 2016 which states that there is no significant relationship between ventilation and transmission of TB in the home, but according to observations that air in the house can circulate properly if sufficient ventilation(WHO, 2014; Khan et al., 2016).

The analysis between environmental risk factors and TB cases in this study shows that the most influential factor in TB incidence in Indonesia is floor surface and location of the kitchen that is separate from the main room. The number of family members increases the risk of TB transmission in the home environment. Likewise with a kitchen that is not separate, this allows when cooking, the smoke in the house cannot circulate properly. Population density is one of the risk factors for TB (Sayuti, 2013; Sejati \& Sofiana, 2015). Where the more dense the house, the transfer of disease, especially infectious diseases through the air will be easier and faster, if there are family members suffering from TB with positive smear who accidentally coughs. Mycobacterium bacteria Tuberculosis will remain in the air for approximately 2 hours so that it has the possibility to transmit the disease to members who have not been exposed to M. tuberculosis bacteria (Jendra \& Margareth, 2015; Sejati \& Sofiana, 2015).

The analysed of relation between the number of cases of high $\mathrm{Tb}$ in homes with kitchens that are not separate from the kitchen and burned from wood with TB cases are not related (Rea \& Leung, 2018).

Many studies suggest that smoking in the home are a high risk in the development of TB (Sidiq, Wahiduddin, \& Sidik, 2013; Denise Rossato Silva et al., 2018). The results of the analysis carried out in this study do not show the relationship of risk posed by family members who smoke in the home with TB cases that occurred. Smoke factors pose a risk for the development of TB in the home environment (Sayuti, 2013). The greatest impact of smoking in terms of public health issues related to infection is probably the increase in the risk of tuberculosis (Silva et al., 2018). The research in Toronto states that exposure to cigarette smoke in a narrow room can increase the risk of TB, while exposure to cigarette smoke outside the room has a lower risk of TB infection (Padrão et al., 2018; Rea \& Leung, 2018). Chen's 2014 study mentions a correlation between exposure to cigarette smoke and an increase in TB cases, the risk for TB will increase for individuals exposed to passive smoking or cooking with solid fuel. Behavioural interventions including reducing exposure to passive smoking or cooking with solid fuel (Chen et al., 2014).

\subsection{Limitation}

All variables measured are only based on interviews and direct observations during the survey, so there is a possibility of misclassification or information bias (Pangaribuan et al., 2020). The study demonstrates that there are several variation of approaches in variables among rural and urban communities living in areas studied.

\section{Conclusion}

These research study found the more variation than expected in some areas. The participants of survey are pulmonary TB participants who have confirmed bacteriological based on culture examination or microscopic smear examination. The sample of the study were 67.617 population but the number of non-available participant was not include for analyse were 13,415 participants (Ministry of Health, 2015).

The participants with diagnose Tb bacteria confirmed is mostly in men over 34 years. The environment with a floor area of $<8 \mathrm{~m}^{2}$ /person seemingly and the location of kitchen (Not separated from the main living area in the house) that is important factor of bacteria $\mathrm{Tb}$ confirmed, beside other factors could be another risk transmission of TB. The prevention efforts are a factor in strategies to reduce cases across the region and can therefore have critical implications. The reporting and hygiene sanitation as an importance of precautionary measures implemented in the 
community are indispensable for this purpose.

\section{Acknowledgments}

Thanks to the Head of the National Institute Health Research and Development and Head of Centre for Public Health Efforts that have given permission and support so that the Tuberculosis Prevalence Survey (SPTB 2013-2014) in Indonesia can be resolved properly. Thank you to the SPTB team who have collaborated so that this survey can be completed properly.

\section{Authors Contribution}

The Main contributors are Dian Perwitasari and Oster S. Member contributors are Lamria Pangaribuan, Teti Tejayanti, Dina Bisara Lolong, Kristina, Qian Long.

\section{Competing Interests Statement}

The authors have no conflicts of interest associated with the material presented in this paper.

\section{References}

Aldridge, R. W., Zenner, D., White, P. J., Muzyamba, M. C., Loutet, M., Dhavan, P., ... \& Abubakar, I. (2016). Prevalence of and risk factors for active tuberculosis in migrants screened before entry to the UK: a population-based cross-sectional study. The Lancet Infectious Diseases, 16(8), 962-970. https://doi.org/10.1016/S1473-3099(16)00072-40

Chen, M., Deng, J., Su, C., Li, J., Wang, M., Abuaku, B. K., ... \& Wen, S. W. (2014). Impact of passive smoking, cooking with solid fuel exposure, and MBL/MASP-2 gene polymorphism upon susceptibility to tuberculosis. International Journal of Infectious Diseases, 29, 1-6. https://doi.org/10.1016/j.ijid.2014.08.010

Curtis, A. C. (2015). Defining adolescence. Journal of adolescent and family health, 7(2), 1-40. https://doi.org/10.1037/000574

Darmiah, D., Santoso, I., \& Maharso, M. (2015). The Relationship of Residential Density and Physical Quality of Houses in Penda Asam Village, South Barito. Journal Environmental Health: Journal and Application of Environmental Health Engineering, 12(1), 231-237. https://doi.org/10.31964/jkl.v12i1.16

Data and Information Centre, Ministry of Health, Indonesia, 2016. (2016). InfoDatin-2016-TB.pdf.

Data and Information Centre, Ministry of Health, Indonesia, 2018. (2018). Tuberkulosis, InfoDATIN 2018 Ministry of Health RI. Doi: 2442-7659.

Dogin, H. S. (1895). National Criminal Justice Information and Statistics Service Report. U.S. Departement of Justice.

Horton, K. C., MacPherson, P., Houben, R. M., White, R. G., \& Corbett, E. L. (2016). Sex differences in tuberculosis burden and notifications in low-and middle-income countries: a systematic review and meta-analysis. PLoS medicine, 13(9), e1002119. https://doi.org/10.1371/journal.pmed.1002119

Indonesia National TB Program (NTP). (2018). National TB guideline.

Jendra, F. J. D., Margareth, R. S., \& G. D. K. (2015). The Relationship of Risk Factors ForAge, Sex, And Occupancy Density With Pulmonary TB Incidence In Wori Village, Wori Sub-District. Journal of Community and Tropical Medicine, 3, 57-65.

Kebede, A. H., Alebachew, Z., Tsegaye, F., Lemma, E., Abebe, A., Agonafir, M., ... \& Onozaki, I. (2014). The first population-based national tuberculosis prevalence survey in Ethiopia, 2010-2011. The International Journal of Tuberculosis and Lung Disease, 18(6), 635-639.

Khaliq, A., Khan, I. H., Akhtar, M. W., \& Chaudhry, M. N. (2015). Environmental risk factors and social determinants of pulmonary tuberculosis in Pakistan. Epidemiology (sunnyvale), 5(3), 201. https://doi.org/10.4172/2161-1165.1000201

Khan, F. A., Fox, G. J., Lee, R. S., Riva, M., Benedetti, A., Proulx, J. F., ... \& Menzies, D. (2016). Housing and tuberculosis in an Inuit village in northern Quebec: a case-control study. CMAJ open, 4(3), E496. https://doi.org/10.9778/cmajo.20160049

Kurniawati, E., \& Sulistiyorini, L. (2019). Analysis of the Physical Quality of the House with the Presence of Mycobacterium Tuberculosis in the Air. The Indonesian Journal of Public Health, 13(1), 13-24. https://doi.org/10.20473/ijph.v13i1.2018.13-25

L., A. et al. (2015) Physical Environment Factors Related Events Home With Tuberculosis Pulmonary Disease In 
Adults In The Work Area Health District Tatelu North Minahasa.

Lönnroth, K., \& Raviglione, M. (2016). The WHO's new End TB Strategy in the post-2015 era of the Sustainable Development Goals. Transactions of the Royal Society of Tropical Medicine and Hygiene, 110(3), 148-150. https://doi.org/10.1093/trstmh/trv108

Mao, T. E., Okada, K., Yamada, N., Peou, S., Ota, M., Saint, S., ... \& Onozaki, I. (2014). Cross-sectional studies of tuberculosis prevalence in Cambodia between 2002 and 2011. Bulletin of the World Health Organization, 92, 573-581. https://doi.org/10.2471/BLT.13.131581

Ministry of Health of Myanmar. (2010). Report on National TB Prevalence Survey 2009-2010, Myanmar.

Ministry of Health, I. (2015). Indonesia Tuberculosis Prevalence Survey 2013-2014 (Report).

Ministry of Health, R. of I. (2011). Regulation of the Minister of Health of the RI Number: 565/MENKES/PER/III/2011 regarding the National Strategy for Control of TB in Indonesia 2010-2014.

Ministry of Health, R. of I. (2018) Indonesia Health Profile 2018, Ministry of Health RI. Retrieved from http://www.depkes.go.id/resources/download/pusdatin/profil-kesehatan-indonesia/Data-dan-Informasi_Profi 1-Kesehatan-Indonesia-2018.pdf

Ministry of Health, R. of I. (2019). Regulation of the Minister of Health, RI Number 67 Year 2016. https://doi.org/10.1017/CBO9781107415324.004

National Institute Health Research and Development, M. of H. R. (2013). Basic Health Research (Riskesdas 2013). Doi: 1 Desember 2013.

Negin, J., Abimbola, S., \& Marais, B. J. (2015). Tuberculosis among older adults-time to take notice. International Journal of Infectious Diseases, 32, 135-137. https://doi.org/10.1016/j.ijid.2014.11.018

Padrão, E., Oliveira, O., Felgueiras, Ó., Gaio, A. R., \& Duarte, R. (2018). Tuberculosis and tobacco: is there any epidemiological association?. European Respiratory Journal, 51(1). https://doi.org/10.1183/13993003.02121-2017

Pangaribuan, L. et al. (2020). Factors Influencing Pulmonary Tuberculosis Occurrence of 15 Years Old or Above in Indonesia (Tuberculosis Prevalence Survey Data Analysis in Indonesia Year 2013-2014), Buletin Penelitian Sistem Kesehatan, 23(1), 10-17.

Qadeer, E., Fatima, R., Yaqoob, A., Tahseen, S., Ul Haq, M., Ghafoor, A., ... \& Tiemersma, E. W. (2016). Population based national tuberculosis prevalence survey among adults (> 15 years) in Pakistan, 2010-2011. PloS one, 11(2), e0148293. https://doi.org/10.1371/journal.pone.0148293

Rahman, S., \& Ahmed, S. (2017). To assess the tuberculosis situation in urban and rural areas of Bangladesh with special emphasis on the facility of treatment scenarios. Pub Health Res, 7(3), 73-77. https://doi.org/10.5923/j.phr.20170703.03

Raviglione, M., \& Sulis, G. (2016). Tuberculosis 2015: burden, challenges and strategy for control and elimination. Infectious disease reports, 8(2), 33-37. https://doi.org/10.4081/idr.2016.6570

Rea, E., \& Leung, T. (2018). Can we eliminate tuberculosis?: A cluster of tuberculosis cases linked to smoking: An under-recognized challenge for tuberculosis elimination. Canada Communicable Disease Report, 44(3-4), 86. http://dx.doi.org/10.14745/ccdr.v44i03a04.

Sayuti, J. (2013). Smoke as one of the risk factors for the incidence of smear positive pulmonary tuberculosis. Spatial case analysis of pulmonary tuberculosis in East Lombok Regency (November, pp. 13-23).

Sejati, A., \& Sofiana, L. (2015). Factors Occurrence of Tuberculosis. Journal of Public Health, Indonesia, 10(2), 122-128. https://doi.org/10.15294/kemas.v10i2.3372

Sidiq, N., Wahiduddin, \& Sidik, D. (2013). Environmental Risk Factors for the Incidence of Pulmonary Tuberculosis in the Somba Opu Public Health Center (pp. 29-35). Retrieved from https://media.neliti.com/media/publications/213091-none.pdf

Silva, D. R., Muñoz-Torrico, M., Duarte, R., Galvão, T., Bonini, E. H., Arbex, F. F., ... \& Mello, F. C. D. Q. (2018). Risk factors for tuberculosis: diabetes, smoking, alcohol use, and the use of other drugs. Jornal Brasileiro de Pneumologia, 44(2), 145-152. https://doi.org/10.1590/s1806-37562017000000443

Soemantri, S., Lolong, D. S., Senewe, F. E., Wiryawan, Y., Tejayanti, T., Pangaribuan, L., ... \& Andayasary, L. (2005). Tuberculosis Prevalence Survey in Indonesia 2004. National Institute of Health Research and 
Development Ministry of Health-Republic of Indonesia. Jakarta.

Srivastava, K., Kant, S., \& Verma, A. (2015). Role of Environmental factors in Transmission of Tuberculosis. Dynamics of Human Health, 2(4), 12.

TB DOTS Strategy Coordination. (2014). National Tuberculosis Management Guidelines 2014. Departement: Health Republic of South Africar Retrieved from http://www.sahivsoc.org/upload/documents/NTCP_Adult_TB Guidelines 27.5.2014.pdf

Tobin-West, C. I., \& Isodje, A. (2016). Quality and rural-urban comparison of tuberculosis care in Rivers State, Nigeria. Pan African Medical Journal, 24(1). https://doi.org/10.11604/pamj.2016.24.60.8497

UNDP \& World Bank Group. (2016). Transitioning from the MDGs to the SDGs, The United Nations Development Programme (UNDP) and the World Bank Group (WGG) (pp. 1-176). Retrieved from $\mathrm{http} / /$ www.undp.org/content/undp/en/home/librarypage/sustainable-development-goals/transitioning-from-t he-mdgs-to-the-sdgs.html

Union, I., Tuberculosis, A. and Disease, L. (2014). 'Public Health Action', I (September 2013).

Vaughan, E. B., Van Hulle, C. A., Beasley, W. H., Rodgers, J. L., \& D'Onofrio, B. M. (2015). Clarifying the associations between age at menarche and adolescent emotional and behavioral problems. Journal of youth and adolescence, 44(4), 922-939. https://doi.org/10.1007/s10964-015-0255-7

World Health Organisation [WHO]. (2015). From MDGs to SDGs: General Introduction. Health in 2015: from MDGs to $\quad S D G s, \quad 1(1), \quad 1-13 . \quad$ Retrieved from https://search.ebscohost.com/login.aspx?direct=true \&db=bth\&AN=112592255\&site=ehost-live\%5Cnhttps:/ /sustainabledevelopment.un.org/content/documents/3490griggs.pdf

World Health Organization [WHO]. (2014). Global tuberculosis report 2014 WHO Library Cataloguing-in-Publication Data (pp. 1-171). Retrieved from www.who.int/about/

Wulandari, A. A., \& Nurjazuli, A. M. S. (2015). Risk Factor and Potential of Transmission of Tuberculosis in Kendal District, Central Java. Jur Kes Ling Indonesia, 14(1), 7-13.

\section{Copyrights}

Copyright for this article is retained by the author(s), with first publication rights granted to the journal.

This is an open-access article distributed under the terms and conditions of the Creative Commons Attribution license (http://creativecommons.org/licenses/by/4.0/). 